NBER WORKING PAPER SERIES

\title{
A COMPARISON OF JOB CREATION \\ AND JOB DESTRUCTION IN \\ CANADA AND THE UNITED STATES
}

John Baldwin

Timothy Dunne

John Haltiwanger

Working Paper No. 4726

\section{NATIONAL BUREAU OF ECONOMIC RESEARCH 1050 Massachusetts Avenue \\ Cambridge, MA 02138 \\ May 1994}

This paper is part of NBER's research program in Economic Fluctuations. Any 'opinions expressed are those of the authors and not those of the U.S. Census Bureau, Statistics Canada, or the National Bureau of Economic Research. 
NBER Working Paper \#4726

May 1994

\section{A COMPARISON OF JOB CREATION \\ AND JOB DESTRUCTION IN \\ CANADA AND THE UNITED STATES}

\section{ABSTRACT}

In recent years a growing number of countries have constructed data series on job creation and job destruction using establishment-level data sets. This paper provides a description and detailed comparison of these new data series for the United States and Canada First, the Canadian and United States industry-level job creation and destruction rates are remarkably similar. Industries with high (low) job creation in the U.S. exhibit high (low) job creation in Canada. The same is true for job destruction. In addition, the overall magnitude of gross job flows in the two countries is comparable. Second, the time-series patterns of creation and destruction are qualitatively similar but do differ in a number of important respects. In both countries, job destruction is much more cyclically volatile than job creation. This cyclical asymmetry is, however, more pronounced in the United States. The paper finishes with a characterization of the job flow patterns using a modified Blanchard and Diamond (1992) model.

John Baldwin

Statistics Canada

Ottawa, Ontario

CANADA K1A 0T6
Timothy Dunne Department of Economics University of Oklahoma Norman, OK 73019

John Haltiwanger Department of Economics University of Maryland College Park, MD 20742 and NBER 


\section{Introduction}

Considerable recent research by economists has been devoted to the measurement and analysis of the job-creation and job-destruction processes.' The basic findings of these studies for the United States are that gross job creation and job destruction substantially exceeds the corresponding net changes in employment, the vast majority of job creation and job destruction occurs within sectors as opposed to reallocation of employment across sectors, job creation and destruction vary systematically with plant characteristics such as plant size, and job destruction is much more cyclically sensitive than job creation. As more data series on gross job flows become available for a growing number of countries, the question arises as to how gross job flows compare across countries.

As a first step, this paper examines the cross-country differences and regularities in gross job flows for the United States and Canada. This is a natural step to take for a number of reasons. First, parallel to the measurement efforts in the United States, high quality longitudinal plant-level data for Canada necessary to measure the gross job flows accurately have been developed as well. Data quality and consistency problems inherently plague the measurement of gross job flows. Spurious flows can be generated if longitudinal linkages of establishments are broken mistakenly by changes in ownership structure or statistical processing (e.g., mergers, divestitures, takeovers, ownership changes, name or minor address changes, changes in corporate status, changes in employer tax or other ids, etc.). The datasets underlying the measurement of gross flows for this study are arguably the best

\footnotetext{
' For U.S. studies, see Leonard (1987), Dunpe, Roberts and Samuelson (1989), Davis and Haltiwanger (1990, 1992), Davis, Haltiwanger and Schuh (1994) and Blanchard and Dinmond (1990). In Canada, see Baldwin and Gorecki (1990, 1992). Roberts (1994) compares employment flows for three developing countries Colombia, Chile, and Moroces. Davis, Haltiwanger and Schuh (1994) summarizes a number of shudies for various industrinlized oconomies.
} 
datasets available for avoiding longitudinal linkage problems. ${ }^{2}$ Further, the datasets used for the analysis in this study have been developed sufficiently to allow for measurement of gross flows for a relatively long time interval. Thus, the proximity of the United States and Canada and the similarity of the database development make for a natural testing ground for these newly developed statistics on the dynamics of the labor market. The similarity in the economies provides a useful cross-check for the independent measurement efforts in each country. The differences in the two countries provide a first step in using cross-country evidence to help identify the factors that affect the pace and timing of job turnover.

Our approach pursues two basic lines of inquiry. First, both the time-series and the cross-sectional patterns of job creation and destruction are examined. Given that the U.S. and Canada have experienced relatively similar business cycles over the 1972-1986 period, we ask - Do the time-series patterns of job creation and job destruction look similar in the two countries? We are particularly interested in whether the striking asymmetry in the relative time-series variances of job destruction and creation in the United States is also present in Canada. Additionally, do common industries in the U.S. and Canada share similar patterns of gross job flows? Given that an industry in Canada and the U.S. is likely to use similar technologies and face comparable sunk costs, one might expect that industries characterized by high (low) job tumover in one country would have a tendency to experience high (low) job turnover in the other country. Mitigating these tochnological stories is the

2 See the discussion in the appendix of Davis, Haltiwanger and Schuh for dipcussion of the measuremeat difficulties in messuring grom flows and the diventages of uxing tho Langitudins Reweanch Database (LRD) for this purpose. Similarly, nee Beldwin and Gorecki (19906) for a discusaion of tho merits of the Canadien date. There were many problems in doveloping these dath for this purpose. Many person years want into the developmeat of the data and there is a long list of individunis at both the U.S. Bureall of tho Cenens and Statistica Canada who have been involved in these efforts. Longitudinal linkage problems are an inherent part of developing this type of data because of the continuous process of change that the business population is undergoing. The advantage of these datnsets relativo to others is that there is considerable auxilingy information availablo to aid in the process of creating tho longitudinal links. Nevertheless, gives these difficulties, an important aspect of this cross-country comparicon is to provide a cross check on tho data quality and the meacurement methodology. 
fact that unionization, plant size, and market sizes differ markedly in the two countries.

Second, we present a simple model of gross job flows and the labor market based on Blanchard and Dianond (1992) which helps characterize the role of aggregate and allocative shocks on job creation and job destruction. We then use this model to guide our analysis of Canadian and U.S. job flows data.

The paper addresses these issues utilizing plant-level data on employment changes for Canada and the U.S.. The Canadian data come from Statistics Canada's Annual Censuses of Manufactures and the U.S. data come from U.S. Census Bureau's Longitudinal Research Database (LRD). For this study, considerable effort was made to harmonize the construction of the job flows variables across the two countries. Thus, the data are quite comparable.

The main findings of the paper are:

(1) While the time-series patterns of net changes of employment, job creation, job destruction, and job turnover (the sum of creation and destruction) are similar qualitatively, there are substantial differences in the quantitative variability of the net and gross job flows. In both countries, job creation and destruction are inversely correlated, job destruction is much more volatile than job creation, and job tumover is countercyclical. However, each of these properties is more pronounced in the United States.

(2) Examining cross-sectional data, there is a remarkable similarity in the patterns and magnitudes of the industry-level average job-creation and destruction rates. Two-digit industries with high (low) levels of job creation, job destruction, job turnover, and net employment change in Canada have correspondingly high (low) values in the U.S..

(3) Using pooled cross-sectional time-series data on U.S. and Canada job flows data, variation in job flows is explained, 10 a large part, by industry and year effects. Country effects, while statistically significant, have little explanatory power when modeling job flows variation.

(4) The remarkably similar industry patterns strongly point towards technological differences as the predominant factor accounting for betweenindustry differences in job flow rates. Further evidence in support of this interpretation is the finding that in both countries the cross-industry variation in the job flows is tightly connected to cross-industry differences in the size distribution of employment. That is, in both countries, industries where the 
typical worker is employed at a large plant have substantially less job turnover than industries where the typical worker is employed at a small plant. In addition, the cross-industry patterns of the size distribution of employment are very similar across the two countries.

The paper is organized in the following fashion. The next section describes the datasets used and basic measurement of job flows. The third section provides a comparison of job flows in Canada and the U.S.. The fourth section sets out a basic model of job flows and labor markets. The fifth section provides basic estimates of the relative importance of country, industry and year effects. The final section closes with brief concluding remarks.

\section{Data and Measurement Issues}

The main objective of this paper is to compare the patterns of job creation and destruction in the U.S. and Canada. Job creation and destruction are measured as jobs gained and jobs lost--defined simply as the difference in employment in establishments between two periods. The resulting summary measures provide indicators of job turnover at the plant level. Note, however, that differences in the number of workers employed in a plant represent net employment changes in the plant's employment opportunities and do not reflect the change in the composition of employment opportunities or the worlforce. Thus, they provide a lower bound on the total amount of job tumover at the plant level.

The employment flow measures utilized in this study are constructed from individual plant-level micro-data on employment. Total job-creation measures for both Canada and the United States are calculated by summing employment gains at expanding and new establishments within a sector between period $t-1$ and $t$; total job destruction by summing employment losses at shrinking and dying establishments within a sector between period $t-1$ and $t$. Rates of growth between period $t-1$ and $t$ (POS) and rates of decline (NEG) are calculated by dividing total job creation and destruction, respectively, by sector size. Sector 
size $\left(X_{4}\right)$ is calculated as the average of employment between period $t-1$ and $t$. The difference between $\mathrm{POS}_{1}$ and $\mathrm{NEG}_{\mathfrak{l}}$ is net employment growth (NET). The sum of POS, and NEG is used to measure the total job-turnover rate (SUM) of a sector between $t-1$ and $t$. These four measures, $\mathrm{POS}_{1}, \mathrm{NEG}_{4}, \mathrm{NET}_{1}$, and SUM, will be the focus of the empirical analyses which follow.

\section{Data}

The data used in this study come from two recently developed plant-level longitudinal databases. The Canadian data are from an annual census of the Canadian manufacturing sector and cover the period from 1972 to 1986 . The United States data come from the Annual Survey of Manufactures covering the period 1972 to 1986 . The details of the construction of these datasets can be found in Baldwin (1990a, 1990b) for the Canadian data, and Davis, Haltiwanger and Schuh (1994) for the U.S. data.

Many previous cross-country comparisons of various aspects of intra-industry mobility have suffered from a lack of data comparability. ${ }^{3}$ This is mainly the result of differences in the way statistical agencies collect and organize data on firms and their plants. In order to improve the relative comparability of the Canadian and U.S. plant-level job flows data, samples and definitions used for the estimates were carefully harmonized." In the Canadian case, this meant using a larger sample than previously; in the United States, it meant using a more restrictive definition of birth and deaths. As a result, some of the turnover estimates

\footnotetext{
'A recent example of just such a probleo can be found in the Cable and Schwalbach abudy (1991) thet compares entry retes across countries. Canedien eatry date which were constructed especinlly for that study to include greenfield and merger entry are set side by side with U.S. dete thet cover busically colly greenfield entry.

4 This included augmenting the Canedien data with a sot of emaller cotablishments, reaggregating industry groups, and rodefining birth and death criteria for the U.S. data.
} 
for Canada and the United States reported herein will not match previous calculations."

\section{Basic Patterns of Job tlows in Canada and the U.S.}

This section provides a description and comparison of the patterns of job nows in Canada and the U.S. over the 1972-1986 period. The analysis is twofold. First, the timeseries fluctuations of job creation and destruction are examined. Next, the average annual rates of job creation and destruction are disaggregated by two-digit industry.

\section{Time Variation of U.S. and Canada Job flows}

Table 1 presents annual rates of job creation (POS) and destruction (NEG), net employment growth (NET) and the total tumover rate (SUM) for Canada and the United States. Previous research in both countries (Baldwin and Gorecid, 1990b; Davis and Haltiwanger 1990) has stressed that job creation and destruction occur simultaneously. In Canada, net change is negative in 1974,1977, 1979, 1982 and 1983; but there is substantial job creation in these years-more than 7 per cent in each year of negative net job growth. The same pattern can be found in the United States where there is substantial job creation even when net rates of change are negative.

The two countries differ in terms of net job creation. The Canadian manufacturing sector experiences small but positive growth over the period being studied; manufacturing in the United States declines at an annual rate of $1.2 \%$ annually. The total turnover rate (SUM) is equally high in both countries averaging about $20 \%$ annually. It does not differ significantly in the two countries. It also has very much the same range in both

\footnotetext{
IIn particular, for the Canadian date compare the numbers reported berein to Baldwin and Gorecki (1987b, 1990, and 1990b) and the US date in Davis and Haltiwner (1992).

- There is a discrepancy between the estimated net employment growth from the LRD and the implied net growth from the published Annual Survey of Manufactures (ASM) data. The reasons for this discrepancy are discussed at leogth in Davis, Haltiwanger, and Schuh $(1990,1994)$.
} 
countries--varying from a low of $17 \%$ to a high of $23 \%$. Additionally, the rate of job creation is negatively correlated with the rate of job destruction in both countries. However, this inverse relationship is much more pronounced in the Unitto States where the correlation is $\mathbf{- 0 . 7 8}$ while the same correlation in Canada is $\mathbf{- 0 . 4 7}$.

Figure la and Figure $1 \mathrm{~b}$ show the movements in job creation and job destruction for the U.S. and Canada. The top panel plots the job-creation time series for both countries while the bottom panel graphs the analogous job-destruction series. Examining the top panel, one sees that the job-creation movements differ markedly between the countries in the 19751979 and 1985-1986 periods. The U.S. experienced a much larger contraction in job creation during the 1975 recession than Canada but experienced a more rapid rebound in jobcreation activity in 1976. In the 1985-1986 period, Canada's job creation remained quite high while the U.S.'s dropped off substantially after the 1984 recovery. The rank correlation coefficient for the job-creation series between the two countries is .264 and is not statistically significant at the .05 level. In terms of volatility, job creation is substantially more volatile in the United States.

The patterns of job destruction in the two countries are somewhat more coherent in Canada and the U.S. during the 1972-1986 period. The main difference in the two series appears during the 1975 recession, where the U.S. experienced a sharp increase in job destruction. The rank correlation between the job-destruction series for the two countries is .810. Again, however, job destruction is substantially more volatile in the U.S. relative to Canada.

Figure 2 plots the total job-turnover (SUM) and the net employment-change (NET) series for the two countries. Movements in net changes are similar in the two countries (the rank cross-country correlation is .76 ) as are the fluctuations in total job tumover (cross-country correlation is 0.53 ). Both the Canadian and U.S. job-turnover series have a 
slight upward trend. Fitting a simple linear time trend to both series yields a trend coefficient (standard error) of $0.38(0.094)$ for Canada and $0.11(0.14)$ for the United States. In results not reported here, this difference is also found to exist for most 2-digit industries. To illustrate the magnitude of the increase in Canada, the rate of total job turnover (SUM) averages $18.7 \%$ from 1972 to 1976 and $22.5 \%$ from 1983-1986. In terms of volatility, net employment growth is more volatile in the U.S. and the volatility of total job turnover is very similar in the two countries. The latter may seem surprising since the separate components of total job turnover (creation and destruction) are both substantially more volatile in the U.S. However, the negative covariance between creation and destruction is greater in the U.S. which offsets the higher individual variances.

The cyclical properties of job turnover also differ somewhat between the two countries. As stressed by Davis and Haltiwanger (1990, 1992), job destruction is more cyclically sensitive than job creation in the United States. This is evident from the higher time-series standard deviation of job destruction (3.3) than for job creation (2.2) reported at the bottom of Table 1. As noted at the bottom of Table 1, this implies that the time-series variance of job destruction is more than twice that of job creation. An implication of this striking asymmetry in the time-series volatility of creation and destruction is that gross job turnover is countercyclical. The pearson correlation between the net job-growth rate and jobturnover rate for the U.S. is $\mathbf{- 0 . 5 4}$. These same qualitative patterns hold for Canada, but the quantitative effects are somewhat muted. The time-series standand deviation of job destruction (2.2) does exceed that of job creation (1.8) for Canada. This implies that the time-series variance of job destruction is about one and one half times larger than the variance of job creation. Further, the time-series correlation between net job growth and total job turnover is -0.25 . As Figure 2 shows, part of the reason for the smaller Canadian correlation is that the Canadian tumover rate exhibits a significant positive trend. Hence, as 
the Canadian manufacturing sector continued to grow in the mid 1980s, so did volatility.

The magnitude of job creation and job destruction observed both in Canada and the United States is not unique to these countries or developed countries in general. For the industrialized economies, Davis, Haltiwanger and Schuh (1994) summarize a number of studies of individual countries with estimated rates of job turnover that range from 16.0 percent in Germany to 23.5 percent in Sweden. ${ }^{7}$ These rates are quite similar to those reported here for Canada and the United States. For developing countries, Roberts (1994) constructs job flows statistics for three developing nations, Colombia, Chile and Morocco. He finds that gross job flows substantially exceeds net employment changes, and that job tumover lies in the range 26.2 and 30.6 for the three countries. This is roughly $25 \%-50 \%$ higher than that found in Canada and the U.S. and other industrialized economies. However, it illustrates the ubiquitous nature of concurrent job creation and destruction in all types of economies.

\section{Cross-Industry Variation in Average Annual Job flows}

Tuming back to the U.S.-Canada comparison, aggregate job-tumover rates may hide substantial differences between Canada and the United States at the industry level. In order to investigate differences in industry-level job flows, the same job-tumover rates were calculated for 2 -digit industries. Table 2 presents the average annual rates for total job creation (POS), total job loss (NEG), net job change (NET) and job turnover (SUM) for

\footnotetext{
' As emphesized in the introduction, there are questions bout dals quality and consiateacy over time for many of these studies. Further, many of these studies are based upon quite short time intervals. An in depth comparison will oaly be possible wbeo comparable date and methodolony are used.
} 
two-digit manufacturing industries in Canada and the United States for the period 19721986. The first point to note is that the patterns of job flows look remarkably similar across the two countries. Sectors that have high job turnover in Canada generally have high job turnover in the U.S.. This is especially true for the Apparel and Lumber industries of both countries. Similarly, sectors such as Paper, Chemicals, Petroleum and Primary Metals have relatively low job turnover in each country. The second point is that industries with high (low) levels of job-creation experience high (low) levels of job destruction. Utilizing the data from Table 2, we construct within-country correlations between job creation and job destruction. The within-country rank correlation (standard errors) between job creation and job destruction is $.672(.0016)$ for the US and is $.831(.0001)$ for Canada.

To illustrate the similarities in industry job flows in Canada and the U.S., Table 3 provides cross-country rank correlations between the Canadian measures of job flows and the U.S. measures. The rank correlations of job creation, job destruction, net employment growth, and job turnover between the Canadian and U.S. data all show strong positive correlations. The rank correlation coefficients between U.S. and Canadian job creation, job destruction, employment growth, and job turnover are $.868, .795, .778$, and .815 , respectively. This suggests that there may be important industry characteristics that are common across countries that help determine the patterns of inter-sectoral job flows. These

\footnotetext{
3he Canadian and US two-digit industry groupings differ in two important respects which affects our dats. First, Canada reports knitting mills separately from otber textile mills. In this case we construct the analogous US industry which incorporates all plants in SIC 225. Second, Canada does not have a separate two-digit industry for scientific equipment as the US does (SIC 38.) The Canadian data for this industry is included in Miscellaneous. In this study, therefore, we include all US producers in SIC 38 in the Miscellaneous caregory as well. Finally, because of disclosure reasons Tobacco is excluded from the analysis. This causes the means at the bottom of Table 2 to differ from the means reported in Table 1.
} 
industry effects are explored more fully in the second half of the paper.'

Overall, the cross-country comparisons yield several striking patterns. First, qualitatively the patterns of net and gross flows are similar. Both countries exhibit a strong asymmetry in the time-series volatility of job destruction relative to creation. However, there are striking differences in the quantitative patterns. The asymmetry in the cyclical volatility of destruction relative to creation is more pronounced in the United States. Further, the time-series volatility of both the net and the gross flows is greater in the U.S. series. Second, the forces generating cross-industry turnover produce a very similar pattem the two countries. Industries that experience high (low) turnover in Canada have high (low) turnover in the U.S.

\section{A Model of Job flows and the Labor Market}

In this section, we develop a simple model of the dynamics of job creation and destruction. The motivation is to provide structure for interpreting the similarities and differences in the behavior of job flows in Canada and the U.S.

The model is essentially a modification of the model in Blanchard and Diamond (1992). The primary modification is to allow for multiple sectors so that intersectoral differences in the behavior of job flows can be characterized. The determinants of job creation and destruction in each sector are described as follows:

\footnotetext{
- Note, also that employment change due to plent openinge and plant closinge are very similer in the two countries. Industries characterized by high (low) eatry job flows in Cunads have correspondingly high (low) eniry job flows in the US. These results are reported in Baldwin, Dunne, and Haltiwanger (1994.)
} 


$$
\begin{aligned}
& x_{1}-x_{1}\left(w, \alpha_{2}, \theta_{2}\right) \\
& y_{1}-y_{2}\left(w, \alpha_{2}, \theta_{n}\right)
\end{aligned}
$$

where $x_{3}$ is job destruction in sector $s, y_{2}$ is job creation in sector $s, w$ is the wage rate, the $\alpha$ 's are vectors of structural characteristics (e.g.,technology, market structure, entry and exit costs, hiring and firing costs) that influence job creation and destruction in sector $s$, the $\theta$ 's are vectors of shocks that shift job creation and destruction (e.g., aggregate demand shocks, allocative shocks, technology shocks). Job destruction is increasing in the wage rate and job creation is decreasing in the wage rate. This specification makes clear that job creation and destruction are appropriately characterized as the decomposition of the change in labor demand into plants expanding and plants contracting employment, respectively.

The job creation described in (2) is desired job creation. The hiring or matching process to accommodate this desired job creation is given by:

$$
h_{a}=m_{0}(u, v)
$$

where $h_{0}$ is hires in sector $s, u$ is the unemployment rate, and $v_{0}$ is the vacancy rate in sector s. The matching function is increasing in $u$ and $v$. This matching function captures the notion that there are frictions in the process of matching firms creating jobs and workers seeking jobs. Empirically, Blanchard and Diamond (1990) found that the matching function approximately exhibits constant returns to scale. Firms and sectors are heterogenous but workers are homogenous. Hence, hires and vacancies are indexed by $s$ but all firms hire from the common unemployment pool. Further, the only source of worker turnover is job turnover - that is, there are no quits due to either bad matches of workers to job slots or labor force exits.

Wages are determined by a Nash bargaining process summarized by: 
where the wage function is increasing in the ratio $(u / v)$.

Labor force growth is given by:

$$
l=k(w, \epsilon)
$$

where 1 , the labor force growth rate, is increasing in $w$ and $\epsilon$ is a set of factors that shift the labor force growth rate.

Aggregate job destruction, hires, vacancies and job creation are by construction given by:

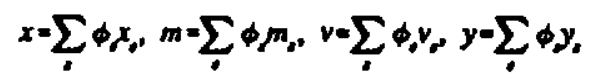

where $\phi_{a}$ is the employment share of sector s.

The connection between job creation and destruction and unemployment and vacancy dynamics is given by:

$$
\begin{aligned}
& \frac{d u}{d}-x-m-1 \\
& \frac{d v_{d}}{d t}-y_{d}-m_{0}
\end{aligned}
$$

Equations (7) and (8) are the heart of the model. They describe the precise relationship between job flows and unemployment and vacancies. It is clear from (7) and (8) that short run dynamics of job creation and destruction will be influenced by the wage determination process, the matching process, the structural characteristics $(\alpha)$ and the aggregate and allocative shocks $(\theta)$. The steady state relationship implied by equations (7) and (8) is given by: 


$$
y-x=l ; y,-m,
$$

In the steady state, aggregate net job creation must equal labor force growth and desired job creation must equal hires in each sector. Note that individual sectors need not satisfy the net job creation equal to labor force growth relationship. That is, even in the steady state, some sectors may have higher than average net job creation while others lower than average net job creation. This suggests that $(9)$ is best interpreted as an "intermediate" run steady state that does not require a steady state distribution of sectoral employment shares. Steady-state distribution of sectoral employment shares requires:

$$
\frac{d \phi_{1}}{d x} \frac{1}{\phi_{1}}=\left(y,-x_{0}\right)-(y-x)=0
$$

In the long run, all sectors must satisfy the net job creation equal to net labor force growth relationship. However, individual sectors may satisfy this relationship but with different gross rates of job creation and destruction. Further, and most importantly, equation (10) implies that sectors with higher than average rates of job creation must also have higher than average rates of job destruction in the long run.

Key features of the model are illustrated in Figure 3 for a hypothetical economy with two sectors. Figure 3a depicts the long-run steady state. In the case depicted, sector 1 is a low job-tumover sector and sector 2 is a high job-turnover sector. In terms of the model, this is generated by differences in the structural characteristics in the two sectors. Note that by construction, the aggregate job creation and destruction rates are employment weighted averages of the sectoral rates. For simplicity, the two sectors are depicted as having equal weights and there is no long-run labor force growth in all panels of Figure 3. Figure 3b illustrates an intermediate run steady state. Sector 1 has higher creation than destruction while sector 2 has higher destruction than creation, while in the aggregate job creation equals 
job destruction (recall the zero labor force growth assumption for this figure). In the aggregate, net job creation equals labor force growth but this is not true for individual sectors in this intermediate run steady state.

Figure $3 c$ depicts the impact of an adverse aggregate shock starting from the steady state depicted in Figure 1a. The adverse aggregate shock causes job destruction to rise and job creation to fall in both sectors. One fundamental question is whether job creation and destruction respond symmetrically to an aggregate shock. Empirically, Davis, Haltiwanger and Schuh $(1990,1994)$ and Blanchard and Diamond (1990) find that job destruction responds disproportionately to aggregate shocks in the U.S.. Potential explanations for this asymmetry are explored in these latter two papers as well as Caballero and Hammour (1992) and Mortensen and Pissarides (1992). For the present purposes, we are interested in determining whether the nature of the cyclical asymmetry differs between the U.S. and Canada. In the figure, job destruction is depicted as responding disproportionately to the aggregate shock.

Figure 3d depicts the impact of an allocative shock that hits both sectors. The allocative shock causes job destruction and job creation to rise in both sectors. Here again there may be an asymmetry in the response to allocative shocks. Further, there is no reason that allocative shocks need, in general, to be common and/or have common effects across sectors.

For the Canada and the U.S., we use these features of the model to address the following questions: First, do we find that sectors with high rates of job creation also have high rates of job destruction on average over the sample period? While this ultimately must be the case, it is of interest to know whether over a 15 year horizon this.long-run property is satisfied. Second, are the sectoral rankings of job tumover similar across the countries? In addressing this question, we are particularly interested in whether it is tochnological 
differences across sectors or market structure or institutional differences across sectors that drive differences in the job-flow rates. If it is primarily technology differences, then presumably U.S. and Canada should exhibit similar sectoral patterns. If it is primarily market structure or institutional differences, then Canada and the U.S. may exhibit different sectoral patterns depending on the degree of differences in market structure and institutions across the countries. Finally, even with our limited time-series, we are interested in whether the U.S. and Canada exhibit noticeable secular or cyclical differences in the behavior of job creation and destruction.

\section{Empirical Analysis of Year, Country, and Industry Differences in Job Fows}

To formally investigate the nature and source of the Canada, U.S. differences, we estimate simple OLS regressions with job creation, job destruction, job turnover and net growth as dependent variables with year, country, and industry effects as regressors. In addition, we consider country-year interactions and country-industry interactions. The objective of this exercise is to quantify the alternative sources of variation in the data.

Table 4a reports F-tests from these regressions. First, there are statistically significant differences in job creation and net employment growth by year, by industry and by country. Second, while job destruction has significant year and industry effects, there are no significant U.S.-Canada differences in the mean rate of job destruction. Third, the interaction of year and country is statistically significant for all measures. Fourth, the country-industry interactions are not statistically significant for net employment growtb but are significant for job creation, job destruction and job turnover.

While Table $4 a$ reveals considerable statistical significant differences by year, country and industry, Table $4 \mathrm{~b}$ provides perspective on the quantitative importance of these differences by reporting the adjusted $R^{2}$ associated for alternative specifications. The results 
are striking. First, country effects have almost no explanatory power in accounting for variation in any of the measures. Second, industry effects have a very large role in accounting for variation in job creation, job destruction, and total job turnover but a minimal role in accounting for variation in net employment growth. The importance of industry effects is especially pronounced for total job tumover. Third, year effects are very important in accounting for variation in net employment growth and are somewhat less important for variation in gross job flows. Fourth, year effects play a more important role in the variation of job destruction than in the variation of job creation. This reflects the asymmetry in the cyclicality of job destruction and creation.

The picture that emerges from Table 4 is that Canada and the U.S. look very similar in the long run in terms of the industrial structure of job creation, destruction, turnover and growth. It is important to note in this regard that there are large cross-industry differences in job-flow rates. Nevertheless, the U.S. and Canada line up very similarly. However, Canada and the U.S. exhibit considerable year-to-year differences in each of these measures. In terms of the model, this suggests that the two countries have very similar $\alpha$-distributions but are subject to different shocks (experience different $\theta$ 's). Further, the more pronounced asymmetry in the relative variances of job destruction and creation in the U.S. suggests that the propagation of cyclical shocks may be somewhat different in the two countries (in terms of the model, this is the response of $x$ and $y$ to $\theta$ ).

The time-series differences in the Canada, U.S. job-flow rates are depicted in Figure 4. Specifically, Figure 4 depicts the year-country interaction coefficients, controlling for common industry and year effects. In contrast to the striking similarity in terms of long-run rates, Figure 4 depicts substantial year-to-year differences. Three features stand out from this figure. First, the largest time-series differences are in the net rather than the gross 
flows. Second, there is no obvious time trend in the differences. ${ }^{10}$ Third, the difference is linked to the business cycle. Job destruction rises more rapidly in recessions in the U.S. than in Canada. Job creation rises somewhat more rapidly in recoveries but this effect is relatively short-lived. Put together, the countercyclicality of job turnover is more pronounced in the U.S. than in Canada.

The above results indicating overwhelming similarity in the cross-industry differences in job-tumover rates between countries can be directly interpreted in light of the steady state predictions of the model presented in section IV. This can be seen by examining the empirical analogue of Figure 3. Specifically, we consider time-series averages by 2-digit industry and plot them in the fashion suggested by Figure 3. The results of this exercise are depicted in Figures Sa and Sb, for Canada and the U.S. respectively. Each 2-digit industry is labeled with its SIC number (see Table 2 for correspondence).

Two illustrative results emerge from this exercise. First, industries do line up approximately on the $45 \%$ line. That is, as predicted by the model, high job creation industries are also high job-destruction industries." Ultimately, this is not surprising but it is interesting that a 15 year period is sufficient for this "steady-state" result to emerge. Second, and more importantly, the ranking of industries in this manner is very similar in the U.S. and Canada (which is precisely what the regression results told us). Within the context of the model, this suggests that there are common factors in the two countries yielding similar industry rankings of job-flow behavior.

\footnotetext{
${ }^{10}$ For the Uniled Stales, business cycle turning points besed on NBER refereace cycle chronology for this period are as followe. Cyclical peaks: November 1983, January 1980, July 1981. Cyclical troughs: March 1975, July 1980, December 1982.

"It is true that for the United States many industrien lie to the right of the 45 degree line given the net contraction of manufacturing employment in the United States. However, it is still the case that the 15-year industry averages exhibit the property that high job-creation industries also are high job-destruction industries - it is this prediction of the steady-state model that we are referring to in this context.
} 
These results strongly point towards technological differences as the predominant factor accounting for between-industry differences in job-flow rates. Canada and the U.S. share the same technology and have the same striking cross-industry patterns in job-flow rates. Further evidence in support of this interpretation is presented in Figure 6 which shows that an industry characteristic that lines up well with the job-flow rates is the average size of the plant at which the typical worker is employed (the coworker mean). ${ }^{12}$ The crossindustry differences in the coworker mean can be interpreted as reflecting differences in the scale and sunkness of operations across industries. ${ }^{13}$ Figure 6 illustrates a tight connection between the coworker mean of an industry and its job-turnover rates. Here, industries are depicted in the manner suggested by the model but labeled by their ranking by coworker means. High tumover industries are clearly depicted as having relatively low coworker means.

\section{Concluding Remarks}

Recently developed longitudinal datasets in the United States and Canada permit a

13 The coworker mean is developed and analyzed in Davis and Haltiwanger (1990). It is litenilly the conployment weighted average size of the extablichment. It is a aummary measuro which in contrist to the average establishment size captures the notion that while the typical establishment is amall, the typical worker works for a large establishmeot. For example, the average establishment size in the manufincturing sector in the United Stutes in 1987 is less than 60 workers. In cootrnst, the coworker mean in the U.S. manufecturing sector (the size of the establishmeat for the typical workex) is more then 1700 workers.

13 The cross-industry differences in the coworker mean can also bo interpreted 20 reflecting differences in market structure across sectors. We do not stress this interpretation for two ressons. Fist, if markel etructure differences across industries were important is this context we would expect to obeerve grealer crose-country differences is aet and job-flow rates since there are presumably significant differencen in marked structure scross the two countries. Secood, the precise connection between the size distribution of employment sad market structure is not well understood. In contrast, the connection between the coworker mean sid technologies soems, at least to us, direct and unambiguous. For evidence in support of this interpretation sec Dunne (1993). The latter paper finds a close correspondence behween plant size and the use of new manufucturing technologies. This paper does not attempt a complete investigation of the industry cheracteristic and associnted interpretations that belp account for the common cross-industry differences between countries. Some preliminary analyaic in this direction is presented is Baldwin, Dunne, and Haltiwanger (1994). 
much richer statistical portrait of employment dynamics. Gross job creation and destruction rates are measured in a comparable fashion for these two countries for the analysis in this paper. The remarkable similarity in the magnitude and the cross-industry variation in rates is striking for a number of reasons. First, it suggests that these remarkably large rates of job creation and destruction in each country are being measured accurately. It is a striking fact in both Canada and the U.S. manufacturing sectors that roughly one in ten jobs is destroyed every year and one in ten jobs is created. While the datasets used for this study are arguably the very best available for avoiding longitudinal linkage problems that plague the measurement of gross flows, this cross-country comparison provides substantial further support for the accuracy of these new statistics.

Beyond providing support for the accuracy of the statistics, the results in this paper are striking in what they tell us about the nature of the similarities and the differences between Canada and the United States. Canada and the U.S. undoubtedly differ in their institutions, in their market structures and in the shocks impacting the economy. However, only the latter come through as having a strong effect. The common technology as well as other common elements dominate the long-run structural relationships across industries. Accordingly, it is difficult to distinguish between the countries in terms of the industrial structure of net and gross job-flow rates. 


\section{References}

Baldwin, J.R., T. Dunne, and J. Haltiwanger. 1994. "Job Change in the Manufacturing Sectors of Canada and the United States," forthcoming in J.R. Baldwin The Dynamics of Industrial Competition, Cambridge University Press.

Baldwin, J.R. and P.K. Gorecki. 1986a. The Role of Scale in Canada-U.S. Productivity Differences in the Manufacturing Sector. Volume 6, The Collected Research Studies, Royal Commission on the Economic Union and Development Prospects for Canada. Toronto: University of Toronto Press.

Baldwin,J.R. and P.K. Gorecki. 1987. "Plant Creation Versus Plant Acquisition: The Entry Process in Canadian Manufacturing," Intemational Joumal of Industrial Organization 5, 27-41.

Baldwin, J.R. and P.K. Goreck. 1990a. "Measuring Firm Entry and Exit with Panel Data," in A.C. Singh and P. Whitridge (eds) Analysis of Data in Time. Ottawa: Statistics Canada.

Baldwin, J.R. and P.K. Gorecki. 1990b. Structural Change and the Adjustment Process: Perspectives on Firm Growth and Worker Turnover. Ottawa: Economic Council of Canada.

Baldwin, J.R. and P.K. Goreck. 1991. "Firm Entry and Exit in the Canadian Manufacturing Sector," Canadian Joumal of Economics 24: 300-23.

Blanchard, O. and P. Diamond. 1990. "The Cyclical Behavior of Gross Flows of Workers in the U.S.," Brookings Papers on Economic Activity 2:85-155.

Blanchard, O. and P. Diamond. 1992. "The Flow Approach to Labor Markets," American Economic Review 82: 354-359.

Birch, D.L. 1987. Job Creation in America. New York: The Free Press.

Caballero, R. and M. Hammour. 1992. "The Cleansing Effects of Recessions," mimeo.

Cable J. and J. Schwalbach. 1991. "Intermational Comparisons of Entry and Exit," in P.A. Geroski and J. Schwalbach (eds.) Entry and Market Contestability: An International Comparison. Oxford: Blackwell. 1991. 257-81.

Davis, S. and J. Haltiwanger. 1990. "Gross Job Creation and Destruction: Microeconomic Evidence and Macroeconomic Implications," NBER 
Macroeconomics Annual 5, 123-68.

Davis, S., J. Haltiwanger and S. Schuh. 1990. "Published Versus Sample Statistics from the ASM: Implications for the LRD" Proceedings of the American Statistical Association. Business and Economics Statistics Section.

Davis, S. and J. Haltiwanger. 1991. "The Distribution of Employees by Establishment Size: Pattems of Change and Comovement in the United States, 1962-85," Working Paper.

Davis, S. and J. Haltiwanger. 1992. "Gross Job Creation, Gross Job Destruction, and Employment Reallocation," Quarterly Joumal of Economics. 107: 819-863.

Davis, S., J. Haltiwanger and S. Schuh. 1994. Job Creation and Job Destnuction in U.S. Manufacturing: 1972-88, U.S. Census Bureau Monograph (forthcoming).

Dunne, T. 1993. "Plant Age and Technology Usage in U.S. Manufacturing Plants," mimeo.

Dunne, T., M.J. Roberts and L. Samuelson. 1989. "Plant Turnover and Gross Employment Flows in the U.S. Manufacturing Sector," Joumal of Labor Economics 7: 48-71.

Leonard, J.S. 1987. "In the Wrong Place at the Wrong Time: The Extent of Frictional and Structural Unemployment," in K. Lang and J. Leonard (eds.) Unemployment and the Structure of Labor Markets. Oxford: Blackwell.

Mortensen, D. and Pissarides. 1992. "The Cyclical Behavior of Job Creation and Destruction," mimeo.

Organization for Economic Cooperation and Development. 1987. "The process of job creation and job destruction," Employment Outlook. Paris: OECD. 97-220.

Roberts, M. 1994. "Employment Growth and Producer Tumover in Three Developing Countries," mimeo.

Schmalensee, R. 1989. "Inter-Industry Studies of Structure and Performance," in R. Schmalensee and R.D. Willig (eds.) Handbook of Industrial Organization. Amsterdam: North-Holland. 951-1009. 
Table 1

A Comperioon of Annuel liet and

Crose Job-chenge Reter by Yeart

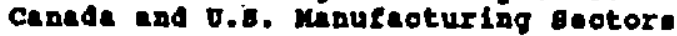

$1973-1986$

Yex

\begin{tabular}{|c|c|c|c|c|c|c|c|c|}
\hline & $\begin{array}{l}\text { Job } \\
\text { Galn } \\
\text { (POa) }\end{array}$ & $\begin{array}{l}\text { Job } \\
\text { Lose } \\
\text { (Neg) }\end{array}$ & $\begin{array}{l}\text { Net } \\
\text { Change } \\
\text { (Net) }\end{array}$ & $\begin{array}{l}\text { Total } \\
\text { Turnover } \\
\text { (Sum) }\end{array}$ & $\begin{array}{l}\text { Job } \\
\text { Gain } \\
\text { (Pos) }\end{array}$ & $\begin{array}{l}\text { Job } \\
\text { Loss } \\
\text { (Neg) }\end{array}$ & $\begin{array}{l}\text { Net } \\
\text { Change } \\
\text { (Net) }\end{array}$ & $\begin{array}{l}\text { Total } \\
\text { Turnover } \\
\text { (Sum) }\end{array}$ \\
\hline 1973 & 11.1 & 6.6 & 4.5 & 17.6 & 11.9 & 6.1 & 5.7 & 18.0 \\
\hline 1974 & 9.7 & 7.7 & 2.0 & 17.4 & 9.0 & 9.3 & -0.0 & 18.3 \\
\hline 1975 & 9.4 & 11.9 & -2.5 & 21.2 & 6.2 & 16.5 & -10.3 & 22.7 \\
\hline 1976 & 9.4 & 9.3 & 0.1 & 18.7 & 11.2 & 9.4 & 1.8 & 20.6 \\
\hline 2977 & 7.8 & 10.2 & -2.2 & 17.9 & 11.0 & 8.6 & 2.3 & 19.6 \\
\hline 1978 & 13.3 & 8.3 & 5.0 & 21.6 & 10.9 & 7.3 & 3.6 & 18.2 \\
\hline 1979 & 12.1 & 8.5 & 3.6 & 20.6 & 10.3 & 7.0 & 3.3 & 17.4 \\
\hline 1980 & 9.8 & 10.1 & -0.3 & 19.9 & 8.0 & 9.1 & -1.1 & 17.1 \\
\hline 1981 & 9.8 & 9.6 & 0.2 & 19.4 & 6.3 & 11.4 & -5.0 & 17.7 \\
\hline 1982 & 7.6 & 15.4 & -7.8 & 23.0 & 6.8 & 14.5 & -7.7 & 21.3 \\
\hline 1983 & 10.7 & 12.9 & -2.2 & 23.7 & 0.4 & 15.5 & -7.2 & 23.9 \\
\hline 1984 & 12.4 & 9.3 & 3.0 & 21.7 & 13.3 & 7.6 & 5.7 & 20.9 \\
\hline 1985 & 12.0 & 9.4 & 2.6 & 21.3 & 7.9 & 11.1 & $-3.2^{-}$ & 19.0 \\
\hline 1986 & 12.9 & 10.5 & 2.4 & 23.3 & 7.9 & 22.1 & -4.2 & 20.1 \\
\hline Mean & 10.6 & 10.0 & 0.6 & 20.5 & 9.2 & 10.4 & -1.2 & 29.6 \\
\hline (std) & 1.8 & 2.2 & 3.4 & 2.1 & 2.2 & 3.3 & 5.2 & 2.1 \\
\hline $\begin{array}{l}\text { Corr } \\
\text { Corr } \\
\operatorname{Var}(\mathrm{N}\end{array}$ & $\begin{array}{l}\text { (Pos, N } \\
\text { (Net, s } \\
\text { leg)/Var }\end{array}$ & a) - & $\begin{array}{ll}-.47 & (0.0 \\
-.25 & (0.3 \\
1.54 & \end{array}$ & $\begin{array}{l}-7 \\
=- \\
=2\end{array}$ & $\begin{array}{ll}78 & (.001) \\
54 & (.04) \\
17 & \end{array}$ & & & \\
\hline
\end{tabular}

Onited atates

canade

Note: std lo standard deviation of the mean. corr la pearson correlation.

SOURCE: Speclal Tabulations: Business and Labour Market Analysis, statiatics Canada and Centre for Economlc studies, Bureau of Censua, Washington 
$\lambda$ Conperteon of Arerege annual tot and orose Job-change Rate by 2-Digit Handaoturing Induatry Cande Vexeua the onlted Btates 1973-1986

Induntry

\begin{tabular}{|c|c|c|c|c|c|c|c|c|}
\hline & $\begin{array}{l}\text { Job } \\
\text { Gain } \\
\text { (POs) }\end{array}$ & $\begin{array}{l}\text { Job } \\
\text { Loss } \\
\text { (Neg) }\end{array}$ & $\begin{array}{c}\text { Net } \\
\text { Change } \\
(\text { Net) }\end{array}$ & $\begin{array}{l}\text { Total } \\
\text { Turnovar } \\
\text { (sum) }\end{array}$ & $\begin{array}{l}\text { Job } \\
\text { Gain } \\
\text { (POs) }\end{array}$ & $\begin{array}{l}\text { Job } \\
\text { Loss } \\
\text { (Neg) }\end{array}$ & $\begin{array}{l}\text { Net } \\
\text { Change } \\
\text { (Net) }\end{array}$ & $\begin{array}{l}\text { Total } \\
\text { Turnover } \\
\text { (Sum) }\end{array}$ \\
\hline Food $(20)^{4}$ & 9.2 & 9.0 & -0.2 & 18.1 & 8.6 & 9.8 & -1.2 & 18.3 \\
\hline Taxt1les (22) & 8.7 & 10.1 & -1.4 & 18.7 & 6.5 & 9.4 & -3.0 & 15.9 \\
\hline nnit. k111:(22.5) & 9.9 & 11.2 & -1.3 & 21.2 & 9.2 & 12.0 & -2.8 & 21.2 \\
\hline Appar $1(23)$ & 13.2 & 13.7 & -0.6 & 26.9 & 10.9 & 14.6 & -3.7 & 25.5 \\
\hline Lumber (24) & 13.1 & 12.6 & 0.5 & 25.7 & 12.6 & 14.6 & -2.0 & 27.2 \\
\hline Furniture (25) & 13.9 & 12.7 & 1.2 & 26.5 & 10.3 & 11.1 & -0.8 & 21.4 \\
\hline Paper (26) & 5.4 & 5.3 & 0.1 & 10.7 & 6.3 & 7.0 & -0.7 & 13.3 \\
\hline Printing (27) & 11.8 & 9.2 & 2.6 & 20.9 & 8.9 & 8.2 & 0.8 & 17.1 \\
\hline Chenlcala (28) & 9.3 & 7.9 & 1.4 & 17.1 & 6.6 & 7.4 & -0.8 & 14.0 \\
\hline Petroleum (29) & 6.8 & 7.3 & -0.4 & 14.1 & 6.3 & B. 4 & -2.1 & 14.6 \\
\hline Rubber (30) & 11.6 & B. 6 & 3.0 & 20.1 & 10.8 & 10.5 & 0.3 & 21.2 \\
\hline Leather (31) & 10.3 & 11.7 & -1.4 & 22.0 & 8.7 & 13.8 & -5.0 & 22.5 \\
\hline $\begin{array}{l}\text { Stone, Clay, } \\
\text { Glass (32) }\end{array}$ & 10.4 & 10.4 & 0.0 & 20.8 & 9.2 & 11.2 & -2.0 & 20.3 \\
\hline $\begin{array}{l}\text { Primary Ketalo (33) } \\
\text { Pabricated }\end{array}$ & 6.4 & 7.1 & -0.7 & 13.5 & 6.5 & 9.7 & -3.3 & 16.2 \\
\hline $\begin{array}{l}\text { Metale }(34) \\
\text { Non-Electrical }\end{array}$ & 13.0 & 11.5 & 1.5 & 24.6 & 9.7 & 11.1 & -1.4 & 20.7 \\
\hline $\begin{array}{l}\text { Machinery (35) } \\
\text { Electrical }\end{array}$ & 13.6 & 12.7 & 0.9 & 26.3 & 10.0 & 10.8 & -0.8 & 20.8 \\
\hline Machinery (36) & 11.1 & 11.5 & -0.3 & 22.6 & 10.0 & 9.8 & 0.2 & 19.8 \\
\hline Transportation (37) & 10.7 & 9.4 & 1.3 & 20.1 & 9.5 & 9.4 & 0.0 & 18.9 \\
\hline Kiecellaneous (39) & 13.4 & 12.4 & 1.0 & 25.8 & 9.9 & 10.7 & -0.8 & 20.5 \\
\hline Total & 10.5 & 10.0 & 0.5 & 20.5 & 9.2 & 10.3 & -1.1 & 19.5 \\
\hline
\end{tabular}

Noten:

Averages correspond to all avallable years for each country 1 isted in rable 1. The United states two-digit standard Industrial code (SIC) Is reported in the parantheses.

SoURCE: Special Tabulations: Businesg and tabour Karket Analysis, statlatica Canada and Cantre for Economic studies, Bureau of census, Washington 
Table 3

Rank Correlatione Between Canada and os mployment Flowa: Croad-Induatry Correletiona*

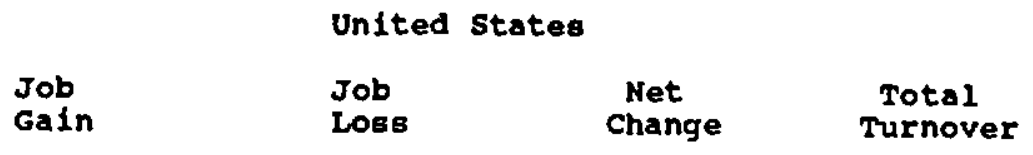

\section{Canada}

Job Gain

$.868^{\circ}$

$.558^{\circ}$

.260

$.719^{*}$

Job Loss

$.761^{\circ}$

$.795^{\circ}$

$-.197$

$.808^{\circ}$

Net Change

.341

$-.245$

$.778^{\circ}$

.003

Tot. Turnover

$3 \% 2$.

$.749^{\circ}$

$-.035$

$.815^{\circ}$

Notes:

'significant at 5 level.

The data underlying the correlations are the two-digit industry averages reported in Table 2 .

SOURCE: Special Tabulations: Business and Labour Market Analysis, statistics Canada and Centre for Economic studies, Bureau of Census, Washington 
Table 4a: F-tests on U.S., Year, and Industry Effects

\begin{tabular}{|c|c|c|c|c|c|}
\hline \multirow{2}{*}{$\begin{array}{l}\text { Malntained } \\
\text { Regressors }\end{array}$} & \multirow{2}{*}{$\begin{array}{l}\text { Marg. } \\
\text { sign. } \\
\text { Level of } \\
\text { Including } \\
\text { : }\end{array}$} & \multicolumn{4}{|c|}{ Dependent Varlable: } \\
\hline & & Pos & NEG & SUM & NET \\
\hline Year, Ind & u.s. & 0.0001 & 0.3200 & 0.0001 & 0.0001 \\
\hline U.s., Ind & Year & 0.0001 & 0.0001 & 0.0001 & 0.0001 \\
\hline u.s., Year & Ind & 0.0001 & 0.0001 & 0.0001 & 0.0001 \\
\hline $\begin{array}{c}\text { U.s. Ind, } \\
\text { Year }\end{array}$ & U.s. Ind & 0.0005 & 0.0033 & 0.0001 & 0.9700 \\
\hline $\begin{array}{c}\text { U.S. Ind, } \\
\text { Year }\end{array}$ & U.s. Year & 0.0001 & 0.0001 & 0.0001 & 0.0002 \\
\hline
\end{tabular}

Table 4b: Summary statistics for U.s., Industry and Year Regresslons

$\begin{array}{ccccc}\begin{array}{c}\text { Adjusted R } \\ \text { with }\end{array} & \text { Dependent variable } & \\ \text { Regressors: } & \text { POS } & \text { NEG } & \text { sU1 } & \text { NET } \\ \text { U.S. } & 0.04 & 0.02 & 0.02 & 0.03 \\ \text { Year } & 0.14 & 0.32 & 0.11 & 0.37 \\ \text { Ind } & 0.35 & 0.23 & 0.58 & 0.02 \\ \text { U.S., Year } & 0.18 & 0.32 & 0.10 & 0.40 \\ \text { U.S., Ind } & 0.39 & 0.24 & 0.59 & 0.05 \\ \text { Ind,Year } & 0.49 & 0.58 & 0.69 & 0.41 \\ \text { U.S.,Ind,Year } & 0.54 & 0.58 & 0.70 & 0.44 \\ \text { U.S., Ind,Year } & 0.57 & 0.59 & 0.76 & 0.43 \\ \text { U.S. Ind } & & 0.62 & 0.73 & 0.55 \\ \text { U.S., Ind,Year } & 0.64 & & & \end{array}$


Figure 1a. Job Creation Canada \& the US

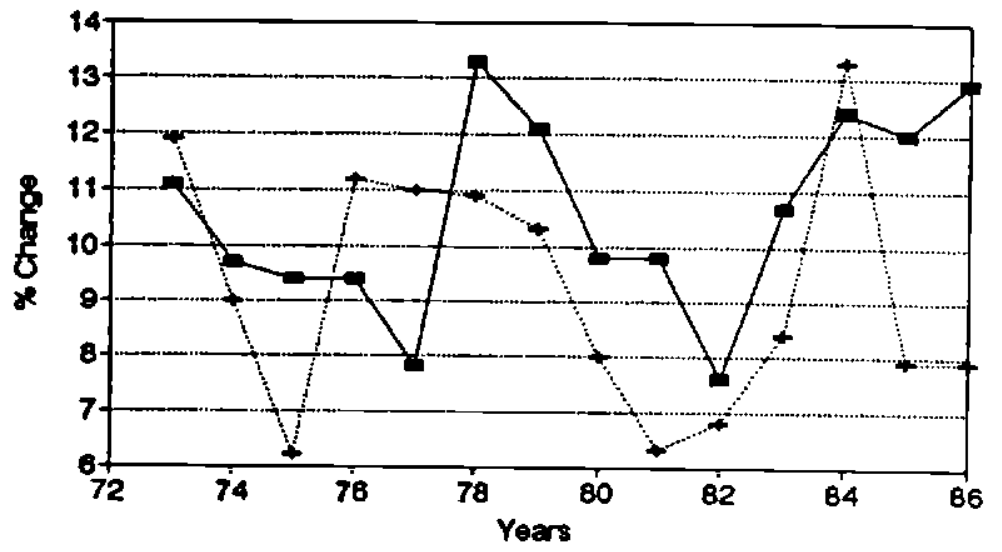

$\rightarrow$ Canada Creation $\rightarrow$ US Creation

Figure 1b. Job Destruction

Canada \& the US

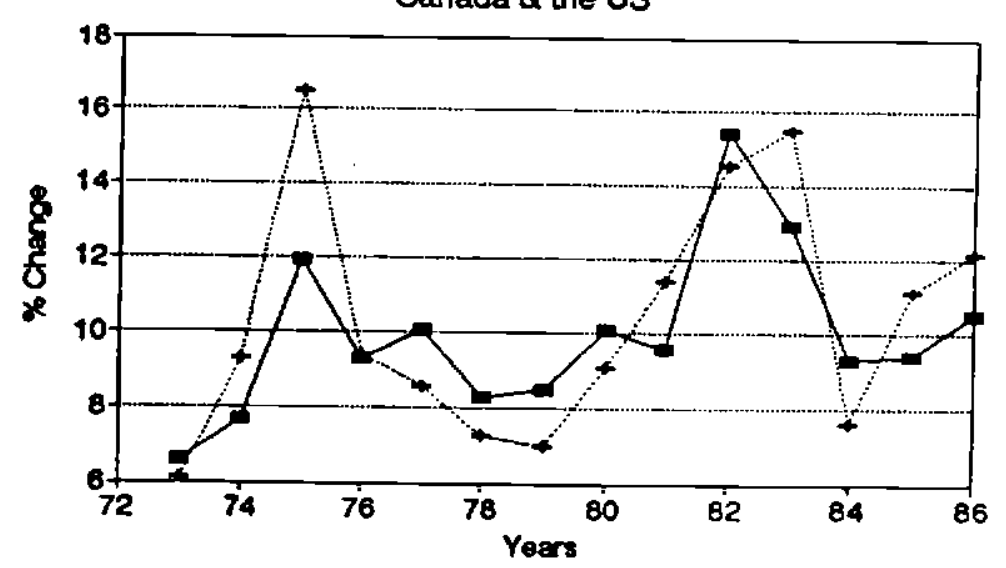

- Canada Destruction - - US Destruction 
Fig. 2. Job Turnover \& Growth Canada \& the US

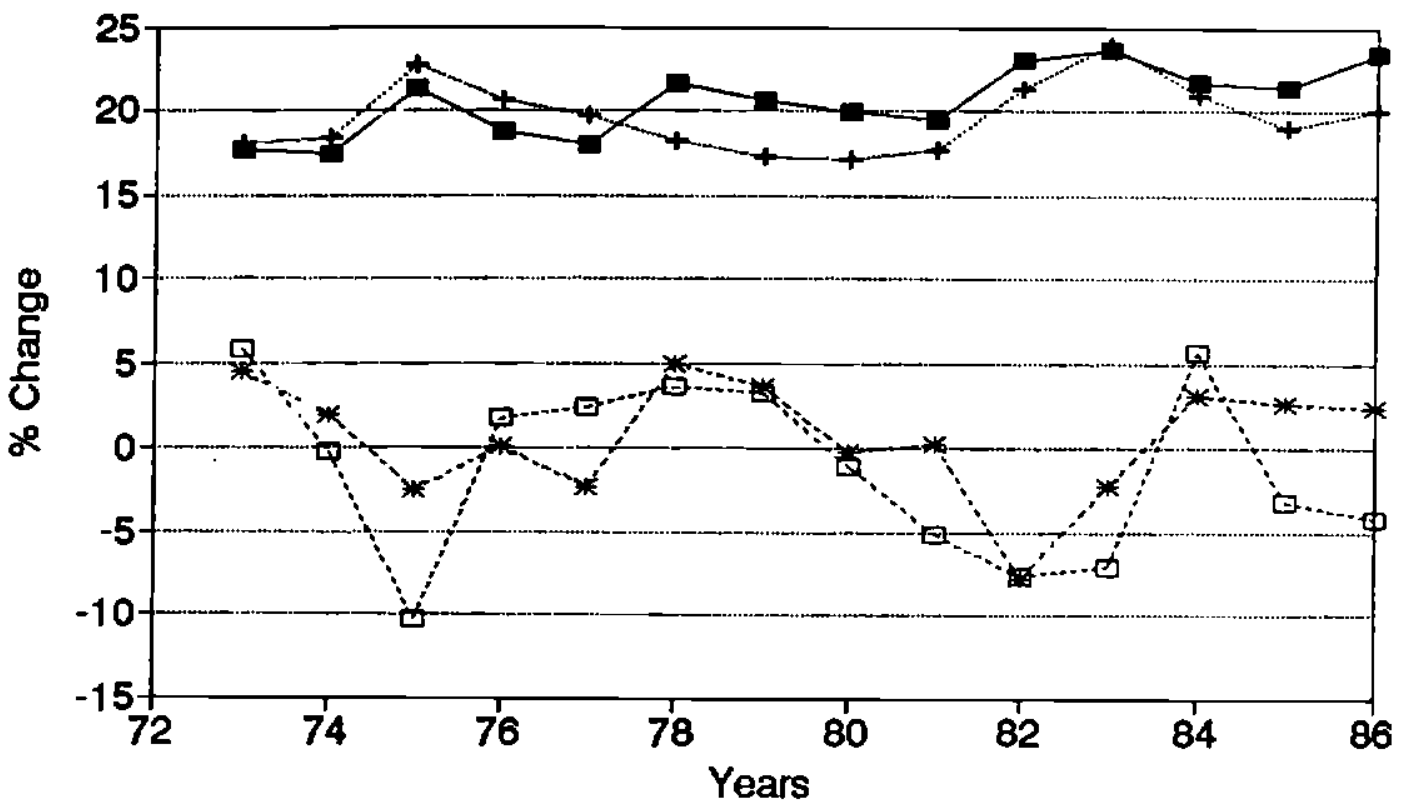

$\rightarrow-$ CN Turnover - + - US Turnover $\cdots * \cdots$ CN Growth $\cdots \boxminus \cdots$ US Growth 
Fig. 3a: Job Creation and Destruction Long fun Steady State

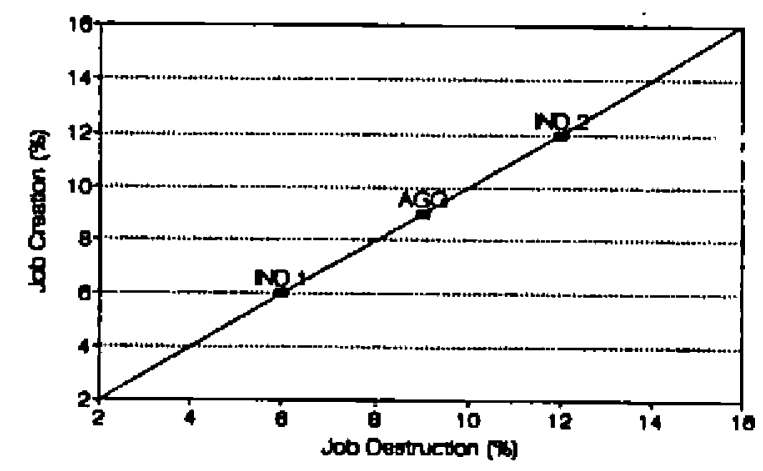

Fig. 3c: Job Creation and Destruction

Aouregate Shock

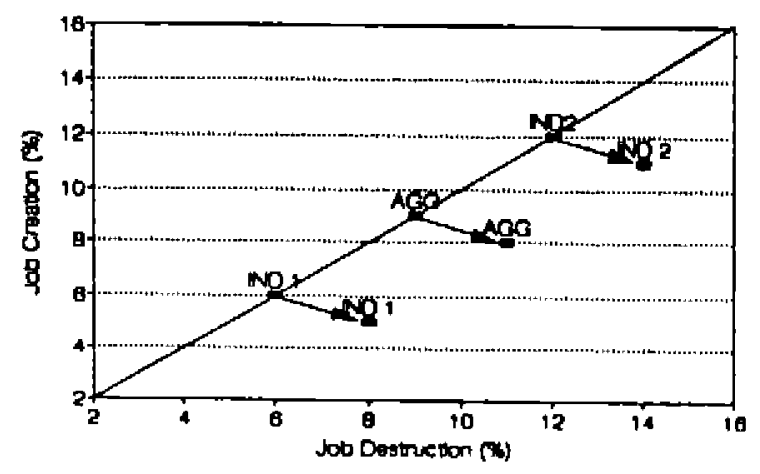

Flg. ab : Job Creation and Destruction intermedlato Run stendy steto.

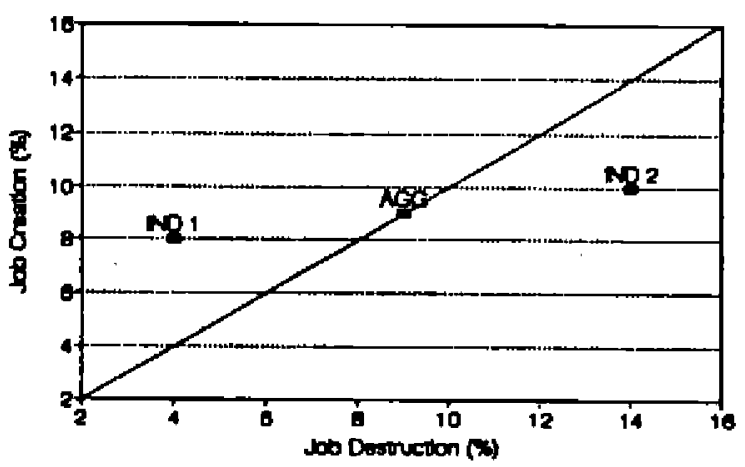

Flg. 3d : Job Creation and Destruction Alocetive shock

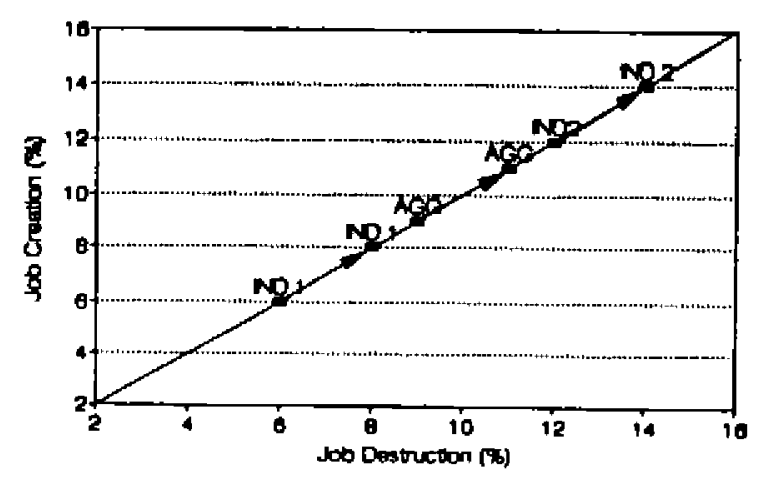


FIG.4 U.S.-CANADA DIFFERENCES IN NET AND GROSS FLOWS, (W/ IND, YEAR CONTROLS)

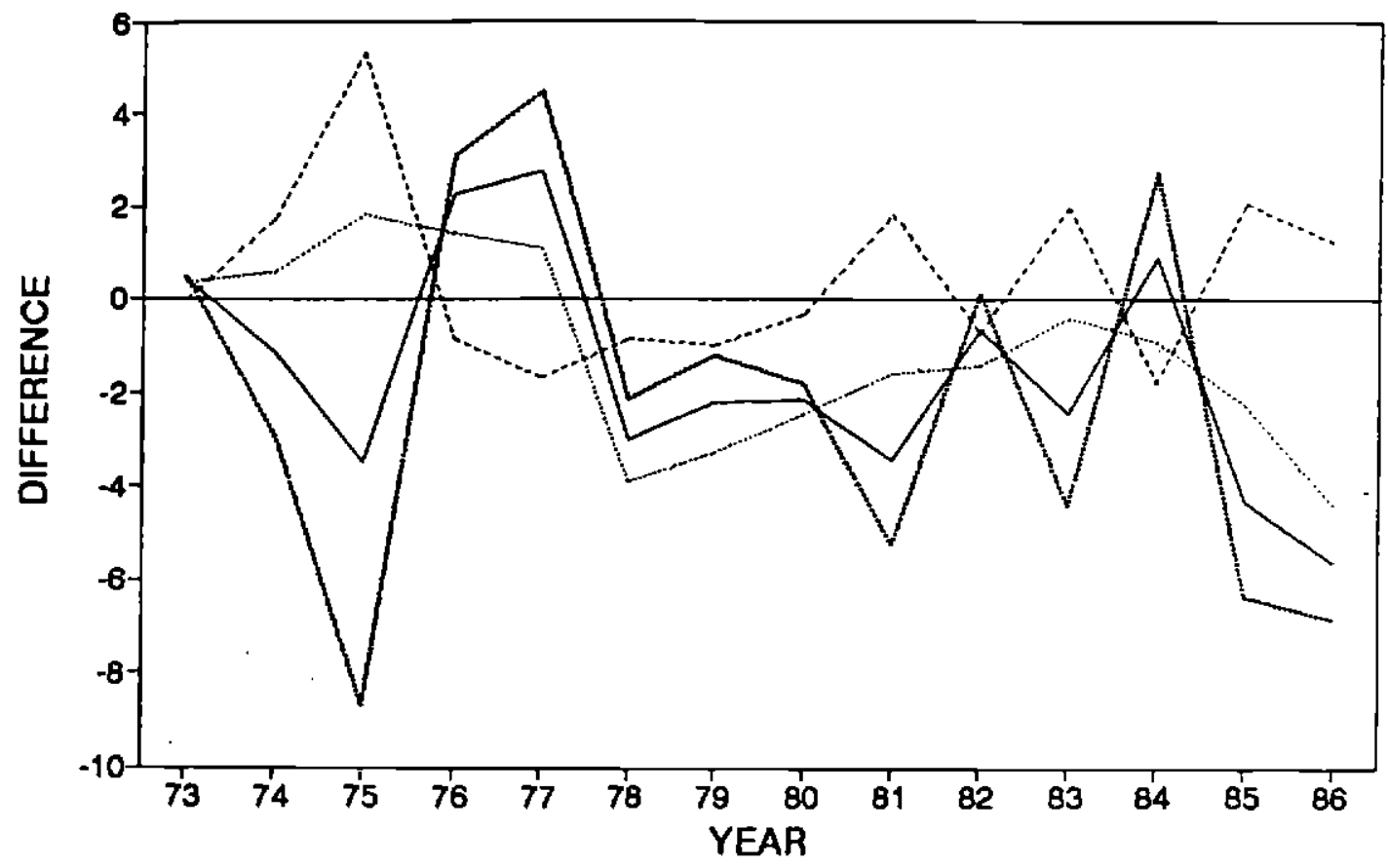

- POS -.... NEG - NET - - SUM 
Figure 5a

Canada: Job Creation \& Destruction

By Two-Digit Industry

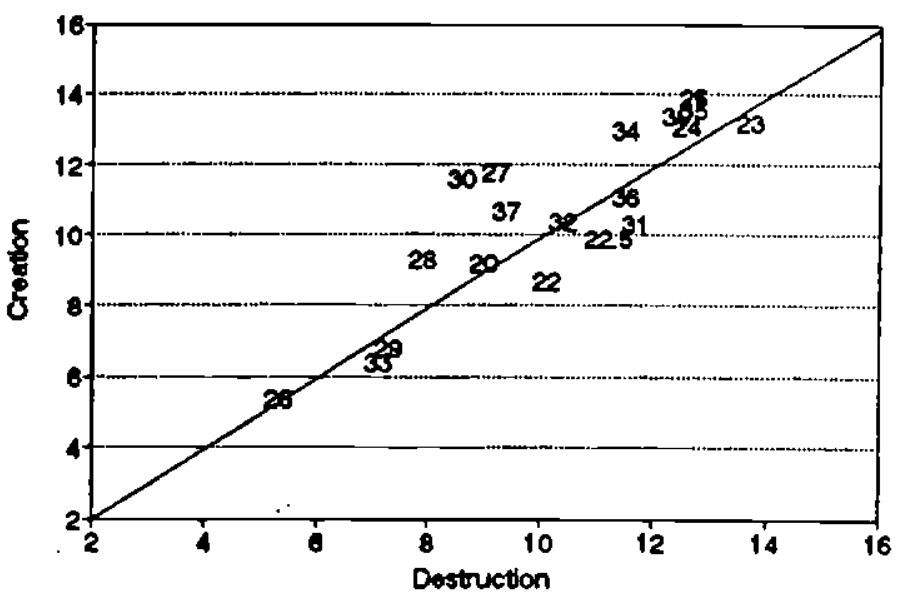

Figure 5b

US: Job Creation \& Destruction

By Two-Dlgit incustry

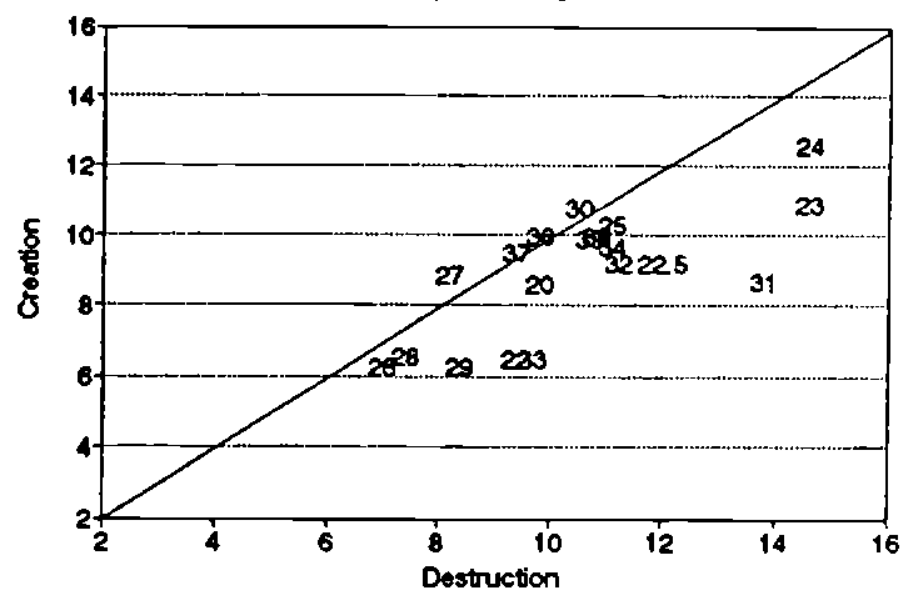


Figure 6a

Canada: Job Creation \& Destruction

Ranked by Co-Worker Means

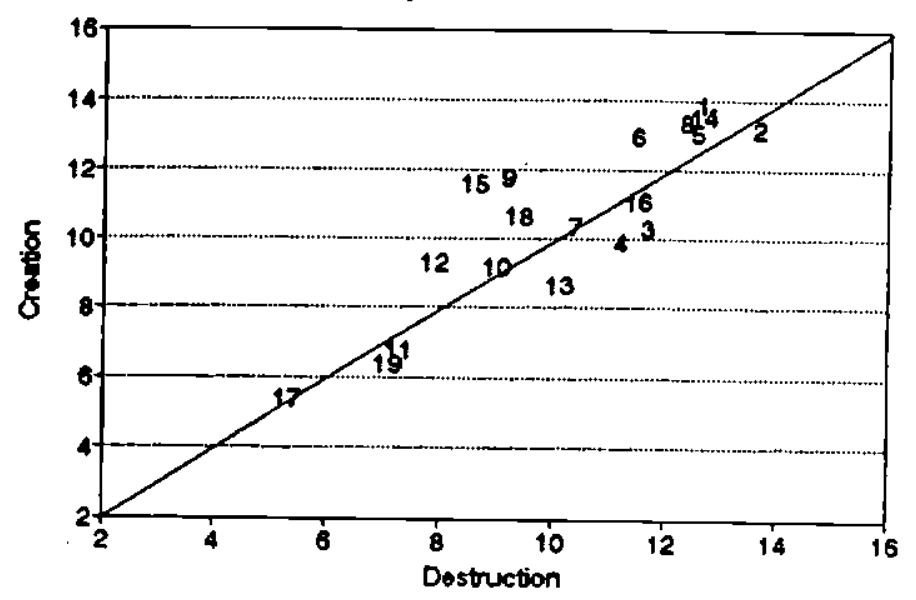

Figure 6b

US: Job Creation \& Destruction Ranked by Co-Worker Means

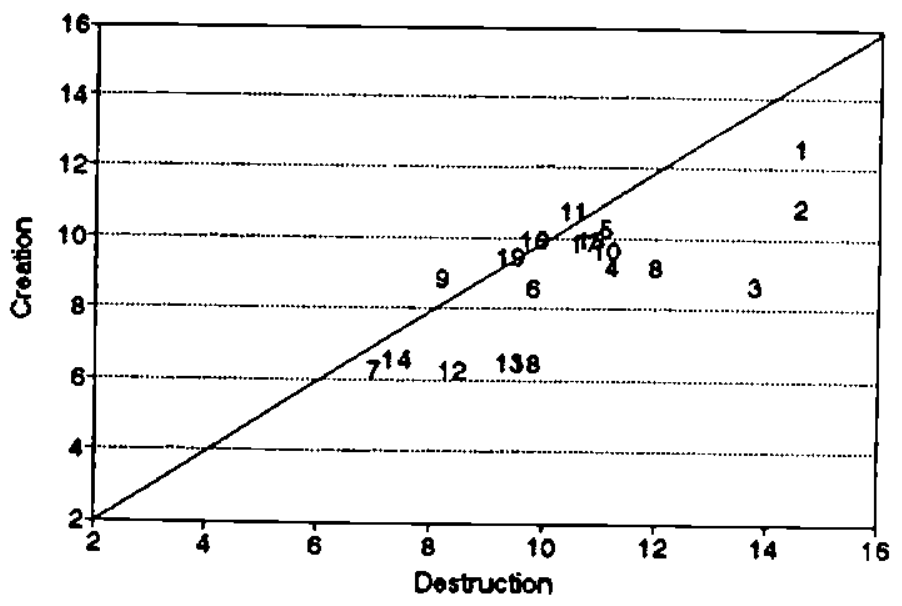

